\title{
Stereotactic Radiosurgery in Pituitary Adenomas: A Single Center Experience
}

\author{
Serdar SURENKOK ${ }^{1}$, Omer SAGER ${ }^{1}$, Ferrat DINCOGLAN ${ }^{1}$, Hakan GAMSIZ $^{1}$, Selcuk DEMIRAL ${ }^{1}$, \\ Bora UYSAL ${ }^{1}$, Sait SIRIN², Kaan OYSUL ${ }^{1}$, Murat BEYZADEOGLU ${ }^{1}$ \\ 'Gulhane Military Medical Academy, Department of Radiation Oncology, Ankara \\ ${ }^{2}$ Gulhane Military Medical Academy, Department of Neurosurgery Ankara, TURKEY
}

\begin{abstract}
The aim of this study was to evaluate the efficiency of stereotactic radiosurgery (SRS) in the management of pituitary adenomas. Between June 1998 and July 2011, 57 patients with pituitary adenomas were treated using SRS at our department. All patients underwent high-precision single dose SRS using a linear accelerator with 6-MV photons. Median follow-up time was 31.5 (3-92) months. Median age was 40 years (range: 19-57 years). Radiological tumor growth control was achieved in 48 patients (84.2\%) (a decrease in tumor size in 25 patients and no change in tumor size in 23 patients). 13 patients with functioning adenomas had available biochemical follow-up and biochemical complete response was achieved in $8(61.5 \%)$ of these 13 patients. Treatment of pituitary adenomas using LINAC-based single dose SRS is safe and effective in improving local tumor and biochemical control.
\end{abstract}

Keywords: Pituitary adenoma, Stereotactic radiosurgery, Growth hormone

\section{ÖZET}

\section{Hipofiz Adenomlarında Stereotaktik Radyocerrahi: Tek Merkez Deneyimi}

Bu çalışmanın amacı stereotaktik radyocerrahi'nin hipofiz adenomu manajmanındaki etkinliğinin değerlendirilmesidir. Kliniğimizde Haziran 1998 ile Temmuz 2011 tarihleri arasında hipofiz adenomlu 57 hasta stereotaktik radyocerrahi ile tedavi edilmiştir. Tüm hastalara lineer akseleratörde $6 \mathrm{MV}$ fotonlarla tek dozda yüksek hassasiyetli stereotaktik radyocerrahi uygulanmıștır. Medyan takip süresi 31.5 ay (sınırlar: 3-92 ay) idi. Radyolojik tümör büyüme kontrolü 48 hastada (84.2\%) sağlanmıştır (25 hastada tümör boyutunda küçülme, 23 hastada tümör boyutunda değişiklik yok). Biyokimyasal takibi mevcut olan fonksiyone adenomlu 13 hastadan 8'inde (\%61.5) biyokimyasal tam cevap elde edilmiştir. Linak tabanlı tek doz stereotaktik radyocerrahi ile hipofiz adenomlarını tedavisi lokal tümör kontrolü ve biyokimyasal kontrolün iyileştirmesinde güvenli ve etkindir.

Anahtar Kelimeler: Hipofiz adenomu, Stereotaktik radyocerrahi, Büyüme hormonu 


\section{INTRODUCTION}

Pituitary adenomas account for $10 \%-20 \%$ of all primary brain tumors..$^{1-3}$ Incidental pituitary tumors are found in approximately $10 \%$ of patients undergoing neuroimaging for other reasons. ${ }^{4}$ These tumors are classified as microadenomas ( $\leq 1 \mathrm{~cm}$ diameter) and macroadenomas ( $>1 \mathrm{~cm}$ diameter) according to their size, and also classified as functioning and nonfunctioning tumors according to their functional hormone secreting status. They are usually benign, slow-growing tumors confined to sella turcica, however, tumor growth may lead to symptoms including visual disturbances particularly in the form of bitemporal visual field loss, headache and hypopituitarism through invasion of surrounding critical structures. Clinical symptoms and laboratory evidence of excess hormone secretion are detected in patients with functioning pituitary adenomas. Symptoms may include amenorrhea, galactorrhea in women and infertility and impotence in men with prolactinoma; acromegaly and gigantism in patients with growth hormone (GH) secreting tumors; Cushing's disease in patients with corticotropin secreting tumors. Involvement of the cavernous sinus may present with ophthalmoplegia, diplopia, and ptosis whereas extension to the sphenoidal sinus may cause cerebrospinal fluid rhinorrhea.

The primary treatment goals in the treatment of pituitary adenomas are controlling tumor growth and normalizing excess hormone secretion in functioning tumors. $30 \%$ of pituitary adenomas are nonfunctioning which are usually diagnosed with symptoms due to tumor growth. ${ }^{5,6} \mathrm{~A}$ combined modality approach with radiotherapy and surgery is effective in preventing local recurrence ${ }^{7}$, however it causes hypopituitarism in half of the patients and may result in complications such as blindness..$^{8-10}$ Fractionated Stereotactic Radiotherapy (FSRT) and SRS are highly conformal treatment techniques delivering high doses to the target while sparing critical structures. Many studies have shown radiotherapy as being a safe and effective therapeutic option, but the close proximity of pituitary region to vital structures including optic nerves, chiasm, cavernous sinus and brainstem increases the risk of possible treatment-related side effects of cranial neuropathies, hypopituitarism, and the risk of secondary malignancies thus placing radiotherapy as the last line of treatment. ${ }^{11,12}$
Surgery is the most commonly utilized treatment modality. Transsphenoidal and transcranial approaches may be used in surgery. Transcranial approach is more frequently preferred for suprasellar tumors owing to the difficulty of transsphenoidal resection in these tumors..$^{13}$ SRS has been used in early 1990s for recurrent and residual pituitary adenomas. ${ }^{14-16}$ Conventional radiotherapy is still the suggested treatment modality for large residual and recurrent tumors. Recently, FSRT has been used for various tumors of the central nervous system. ${ }^{17,18}$ Some studies have shown the superiority of FSRT to single dose SRS and conventional radiotherapy in terms of local control and critical organ sparing. ${ }^{19}$ Radiation therapy or radiosurgery is usually performed post-operatively at adjuvant basis to prevent recurrent tumor growth or at the time of recurrence when clinical symptoms and radiologic progression is evident while it may also be used as a complementary treatment for incomplete surgery in the setting of residual tumor presence.

In this study, the efficiency of SRS in the treatment of pituitary adenomas in terms of local control and biochemical response was evaluated.

\section{PATIENTS AND METHODS}

Between 1998 and 2010, 57 patients with pituitary adenomas were treated using SRS at our department. All of the patients in the current study underwent predominantly transsphenoidal surgery along with transcranial surgery, the combination of both, or no surgery before SRS. An informed consent was obtained from every patient before SRS. Treatment with SRS was decided by a multidisciplinary team including experts on radiation oncology and neurosurgery. Indications of SRS for functioning adenomas included biochemical failure of hormone levels despite medical treatment and progression with enlarged lesion size after surgery whereas SRS was delivered in the setting of subtotal resection and recurrence after surgery for non-functioning adenomas. Tumor size and the distance between tumor and critical structures was measured on Magnetic Resonance Imaging (MRI). A minimum distance of $3 \mathrm{~mm}$ between the optic chiasm and tumor was required for SRS treatment. 


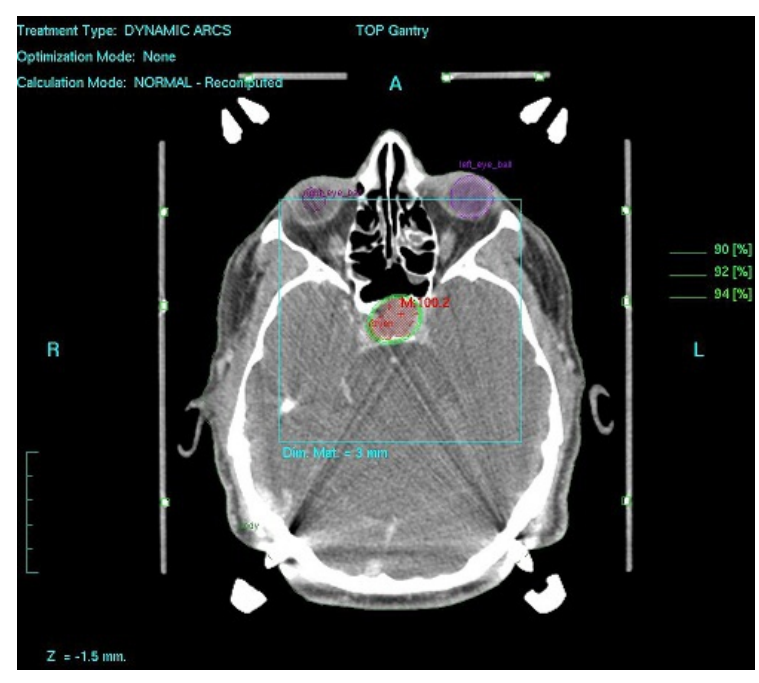

Figure 1a. The isodose distribution of SRS planning

For the first 10 years, SRS planning was performed with XKnife-3 (Radionics, Boston, MA, USA) and treatment was delivered by SL-25 linear accelerator (Elekta, UK). Radiosurgery planning system was then replaced with ERGO ++ (CMS, Elekta, UK) allowing Volumetric Modulated Arc Radiosurgery and the treatments were delivered by Synergy linear accelerator (Elekta, UK) with $3 \mathrm{~mm}$ thickness head-on micro-MLC (micro multileaf collimator). On the day of treatment, a stereotactic frame (Leksell frame or 3D-Line frame, Elekta, UK) was affixed to the patient's skull under local anesthesia with 4 pins, and a planning CT scan usually fused with a prior MRI was used for computerized treatment planning. In the planning; either a single 360degree 18 arc, double 360-degree 36 arcs or five 180-degree 45 arcs were selected to spare the critical structures around the target. Target volume and critical structures were contoured manually by both the treating radiation oncologist and neurosurgeon. Windows and levels of the treatment planning CT were adjusted to improve visualization of the target and critical structures. Coronal and sagittal images were used in addition to axial images to improve target and organ-at-risk (OAR) delineation accuracy. AMOA (Arc Modulation Optimization Algorithm) was used to improve target coverage whithout compromising normal tissue sparing. All patients underwent high-precision single dose SRS using a

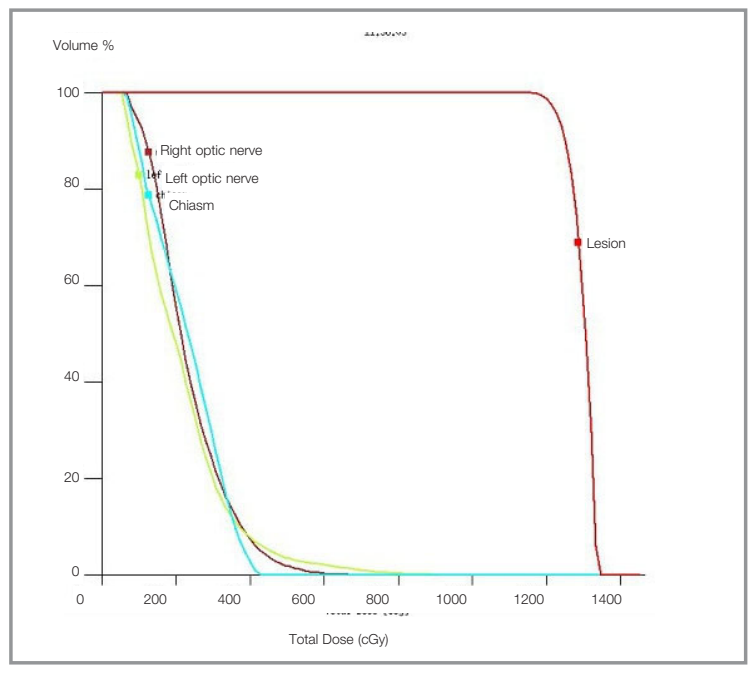

Figure 1b. Dose-volume histogram of the target and critical structures in ERGO planning system

linear accelerator with 6-MV photons. Median dose was 13 Gy (range;10-16 Gy) prescribed to the 83\%-95\% (median 91\%) isodose line encompassing the target. Isocenters of all patients were checked by kV-CBCT (kilovoltage Cone Beam CT) and setup verifications were performed with XVI (Xray Volumetric Imaging, Elekta, UK) system. $8 \mathrm{mg}$ intravenous dexamethasone with $\mathrm{H}_{2}$-antihistamines was used immediately after SRS. Figures $1 \mathrm{a}, 1 \mathrm{~b}$ show the isodose distribution of SRS planning and dose-volume histogram of the target and critical structures in ERGO planning system. After the completion of treatment, follow-up visits were scheduled for every patient routinely at 3-month intervals for the first year, at 6-month intervals for the second year, and annually thereafter including clinical examination with neurologic examination and neuroimaging with contrast-enhanced MRI. Median follow-up time was 31.5 (range; 3-62 months) months. Tumor sizes measured for each patient in three dimensions were compared with pre-SRS measurements to determine the effect of therapy on tumor size. Visual field tests and hormone level measurements were performed before and after SRS and at each follow-up visit. Patients were requested to inform the treating physician about any unexpected neurologic worsening regardless of the followup schedule. 


\begin{tabular}{|ll|}
\hline \multicolumn{2}{|l|}{ Table 1. Patient characteristics } \\
\hline Median age & 40 years (19-57 years) \\
Gender & \\
$\quad$ Male & 30 patients (53\%) \\
Female & 27 patients (47\%) \\
Previous surgery & \\
Transsphenoidal & 24 patients (42.1\%) \\
$\quad$ Transcranial & 4 patients (7\%) \\
$\quad$ Both & 2 patients (3.5\%) \\
Tumor type & \\
$\quad$ Non-functioning & 38 patients (66.7\%) \\
Functioning & 19 patients (33.3\%) \\
Prolactin & 8 patients (14\%) \\
GH & 7 patients (12.3\%) \\
Corticotropin & 4 patients (7\%) \\
Median marginal dose & 13 Gy (10-16 Gy) 83-95\% \\
Radiological tumor control rate & 48 patients $84.2 \%$ \\
Biochemical tumor control rate & $8 / 13$ patient (61.5\%) \\
\hline
\end{tabular}

\section{RESULTS}

Of the 57 patients, 24 patients were treated with transsphenoidal surgery, and 4 patients were treated with transcranial surgery, whereas 29 patients had no surgery because of patient refusal, before SRS. Of the 24 patients treated with transsphenoidal surgery, 9 patients underwent a second transsphenoidal surgery for residual tumors. Two patients had initial transsphenoidal surgery, and underwent transcranial surgery for recurrent symptomatic disease. 30 patients $(53 \%)$ were male and 27 (47\%) patients were female. Median age was 40 years (range;19-57 years). 38 lesions (66.7\%) were nonfunctioning, whereas 19 lesions $(33.3 \%)$ were functioning adenomas. Of the 19 functioning adenomas, $8(14 \%)$ were prolactin secreting, $7(12.3 \%)$ were $\mathrm{GH}$-secreting and 4 (7\%) were corticotropin-secreting. Of the 57 lesions treated, follow-up with MRI revealed radiologic regression in 25 (43.9\%) lesions, no radiologic change in $23(40.3 \%)$ patients, thus 48 patients $(84.2 \%)$ were locally controlled.

Progression of lesion size was detected in the remaining $9(15.8 \%)$ patients. Of these 9 patients, 3 $(5.3 \%)$ were treated with surgery after SRS and the other $6(10.5 \%)$ are still under close follow-up. Of the 9 lesions with progression, the increase in size occured within 12 months in 4 lesions. For the 3 patients treated surgically after SRS, surgical indication was neurological symptoms due to optic chiasm compression (2 patients) and progressive diplopia (1 patient); 1 of these 3 patients recovered visual function after surgery. Of the 9 progressive lesions, 6 were non-functioning and 3 were functioning. Of the 19 patients with functioning adenomas, biochemial outcome assessment was possible in 13 patients. Of these 13 patients assessed, 4 patients were predominantly prolactin-secreting, another 4 patients were predominantly GH-secreting and 5 patients were predominantly corticotropin-secreting. Hormonal levels were normalized for all patients with prolactinoma within 12 months after SRS. Biochemical complete response was achieved in 1 patient with GH-secreting adenoma. Of the 5 patients with Cushing's disease, normalization of corticotropin secretion was achieved in 3 patients within 9 months, the remaining 2 patients received ketoconazole supression treatment which eventually resulted in approximately normal hormonal levels. Of the 19 patients with functoning pituitary adenomas, 13 patients had available biochemical follow-up and biochemical complete response was achieved in 8 of these 13 patients $(61.5 \%)$. Patient characteristics are shown on Table 1.

\section{DISCUSSION}

Pituitary adenomas comprise $10 \%-20 \%$ of all brain tumors. ${ }^{1,2}$ Functioning adenomas cause symptoms primarily due to hormone hypersecretion while non-functioning adenomas are usually diagnosed with symptoms caused by compression of critical structures such as optic chiasm, stalk, cranial nerves in cavernous sinus and 3rd ventricle. For this reason, non-functioning adenomas are usually detected in larger size and frequently present with hypopituitarism and visual field impairment. With radiotherapy and SRS adjuvant to surgery, 93\%97\% local control was achieved in both functioning and non-functioning pituitary adenomas. ${ }^{20-22}$ However, with these adjuvant treatments, a $50 \%$ risk of pituitary deficiency and cognitive impairment exists. $^{23}$

The role of radiotherapy in pituitary adenomas is controversial. Radiation therapy or radiosurgery is 
usually performed post-operatively as adjuvant therapy to prevent recurrent tumor growth or at the time of recurrence when clinical symptoms and radiologic progression is evident while it may also be used as a complementary treatment to incomplete surgery in the setting of residual tumor presence. SRS may also be utilized in unresectable patients. Chang et al. ${ }^{3}$ compared surgery only with surgery and radiotherapy combination in a series of 663 patiets with non-functioning pituitary adenomas. They found the most important factor associated with long-term cure to be gross total resection, and that adjuvant radiotherapy decreased recurrence rates in patients with subtotal excision. Some studies investigated the radiosensitivity of functioning adenomas with respect to secreted hormones. 5-year remission rates after SRS for corticotropin-secreting, GH-secreting and prolactin-secreting tumors were $85 \%, 60 \%$, and $20 \%$, respectively. ${ }^{24}$ In our study, for the GH-secreting tumors, hormonal level normalization was achieved in 1 patient out of 4 patients. Control of acromegaly with a combination of fractionated radiotherapy or stereotactic radiotherapy and medical treatments was achieved only in $7 \%-40 \%$ of the patients at 2 years and in 50\%-90\% of the patients at 10 years. ${ }^{25-27}$ Biochemical failure in patients with $\mathrm{GH}$-secreting adenomas in our study may be attributed to short follow-up. Also of concern is somatostatin treatment used in our study, which may have decreased the radiation effects since it is a radioprotector. ${ }^{28}$ The effective treatment of prolactinomas with dopamin agonists placed radiotherapy as the salvage treatment for medical treatment refractory patients. Hormonal levels were normalized in all followed up patients with prolactinomas in our study. Out of 5 patients with corticotropin secreting adenomas who were periodically followed up, hormonal level normalization was achieved in 3 patients within 12 months after SRS.

\section{CONCLUSION}

Local tumor control and biochemical control is improved with initial or adjuvant LINAC-based SRS in patients with pituitary adenomas.

\section{REFERENCES}

1. Laws ER Jr, Ebersold M, Piepgras DG. The results of transsphenoidal surgery in specific clinical entities. In: Management of pituitary adenomas and related lesions with emphasis on transsphenoidal microsurgery. Laws ER Jr, Randall R, Kern EB (eds). Appleton-Century-Crofts, New York, 1982: 277-305.

2. Laws ER Jr, Vance ML. Radiosurgery for pituitary tumors and craniopharyngiomas. Neurosurg Clin N Am 10: 327-336, 1999.

3. Chang EF, Zada G, Kim S, et al. Long-term recurrence and mortality after surgery and adjuvant radiotherapy for nonfunctional pituitary adenomas. J Neurosurg 108: 736-45, 2008.

4. Chong BW, Kucharczyk W, Singer W, George S. Pituitary gland MR: a comparative study of healthy volunteers and patients with microadenomas. AJNR 15: 675-679, 1994.

5. Milker-Zabel S, Debus J, Thilmann C, et al. Fractionated stereotactically guided radiotherapy and radiosurgery in the treatment of functional and nonfunctional adenomas of the pituitary gland. Int J Radiat Oncol Biol Phys 50: 1279-1286, 2001.

6. Sheline G, Wara W. Radiation therapy of pituitary tumors. In: Neurological surgery. Youmans J, (ed). WB Saunders, Philadelphia, 1990: 3499-3504.

7. Breen P, Flickinger JC, Kondziolka D, Martinez AJ. Radiotherapy for nonfunctional pituitary adenoma: Analysis of long-term tumor control. J Neurosurg 89: 933938, 1998.

8. Rush S, Cooper PR. Symptom resolution, tumor control, and side effects following postoperative radiotherapy for pituitary macroadenomas. Int J Radiat Oncol Biol Phys 37: 1031-1034, 1997.

9. Losa M, Valle M, Mortini P, et al. Gamma knife surgery for treatment of residual nonfunctioning pituitary adenomas after surgical debulking. J Neurosurg 100: 438443, 2004.

10. Paek SH, Downes MB, Bednarz G, et al. Integration of surgery with fractionated stereotactic radiotherapy for treatment of nonfunctioning pituitary macroadenomas. Int J Radiat Oncol Biol Phys 61: 795-808, 2005.

11. Liscak R, Vladyka V, Marek J, et al. Gamma knife radiosurgery for endocrine-inactive pituitary adenomas. Acta Neurochir (Wien) 149: 999-1006, 2007.

12. Ghostine S, Ghostine MS, Johnson WD. Radiation therapy in the treatment of pituitary tumors. Neurosurg Focus 24: E8, 2000.

13. Chandler WF, Barkan AL. Treatment of pituitary tumors: a surgical perspective. Endocrinol Metab Clin North Am 37: 51-66, 2008.

14. Ganz JC, Backlund EO, Thorsen FA. The effects of gamma knife surgery of pituitary adenomas on tumor growth and endocrinopathies. Stereotact Funct Neurosurg 61 (Suppl. 1): 30-37, 1993. 
15. Lim YL, Leem W, Kim TS, et al. Four years' experiences in the treatment of pituitary adenomas with gamma knife radiosurgery. Stereotact Funct Neurosurg 70 (Suppl. 1): 95-109, 1998

16. Jackson IM, Noren G. Role of gamma knife therapy in the management of pituitary tumors. Endocrinol Metab Clin North Am 28: 133-142, 1999.

17. Schulz-Ertner D, Debus J, Lohr F, et al. Fractionated stereotactic conformal radiation therapy of brain stem gliomas: Outcome and prognostic factors. Radiother Oncol 57: 215-223, 2000.

18. Andrews DW, Suarez O, Goldman HW, et al. Stereotactic radiosurgery and fractionated stereotactic radiotherapy for the treatment of acoustic schwannomas: Comparative observations of 125 patients treated at one institution. Int J Radiat Oncol Biol Phys 50: 12651278, 2001.

19. Andrews DW, Faroozan R, Yang BP, et al. Fractionated stereotactic radiotherapy for the treatment of optic nerve sheath meningiomas: Preliminary observations of 33 optic nerves in 30 patients with historical comparison to observation with or without prior surgery. Neurosurgery 51: 890-903, 2002.

20. Hoybye C, Rahn T. Adjuvant gamma knife radiosurgery in non-functioning pituitary adenomas; low risk of long-term complications in selected patients. Pituitary 12: 211-216, 2009.

21. Minniti G, Jaffrain-ReaM-L, Osti M, et al. The long-termefficacy of conventional radiotherapy in patients with $\mathrm{GH}$-secreting pituitary adenomas. Clin Endocrinol (Oxf) 62: 210-216, 2005.

22. Sheehan JP, Niranjan A, Sheehan JM, et al. Stereotactic radiosurgery for pituitary adenomas: an intermediate review of its safety, efficacy, and role in the neurosurgical treatment armamentarium. J Neurosurg 102: 678-686, 2005.

23. McCollough WM, Marcus RB Jr, Rhoton AL Jr, et al. Long-term follow-up of radiotherapy for pituitary adenoma: The absence of late recurrence after greater than or equal to 4500 cGy. Int J Radiat Oncol Biol Phys 21: 607-614, 1991.
24. Pollock BE, Brown P, Nippoldt T, Young WJ. Pituitary tumor type affects the chance of biochemical remission after radiosurgery of hormone-secreting pituitary adenomas. Neurosurgery 62: 1271-1276, 2008.

25. Barrande G, Pittino-Lungo M, Coste J, et al. Hormonal and metabolic effects of radiotherapy in acromegaly: long-term results in 128 patients followed in a single center. J Clin Endocrinol Metab 85: 3779-3785, 2000.

26. Biermasz N, van Dulken $H$, Roelfsema F. Long-term follow-up results of postoperative radiotherapy in 36 patients with acromegaly. J Clin Endocrinol Metab 85: 2476-2482, 2000.

27. Losa M, Gioia L, Picozzi P, et al. The role of stereotactic radiotherapy in patients with growth hormone-secreting pituitary adenoma. J Clin Endocrinol Metab 93: 2546-2552, 2008.

28. Landolt AM, Haller D, Lomax N, et al. Octreotide may act as a radioprotective agent in acromegaly. $\mathrm{J}$ Clin Endocrinol Metab 85: 1287-1289, 2000.

\section{Correspondence}

Dr. Serdar SÜRENKÖK

Gülhane Askeri Tıp Akademisi

Radyasyon Onkolojisi Anabilim Dalı

General Tevfik Sağlam Caddesi

06018, Etlik, Kecioren

ANKARA / TURKEY

Tel: $\quad$ (+90.312) 3044684

Fax: $\quad$ (+90.312) 3044680

E-mail : serdarsurenkok@yahoo.com 